\title{
Estimation of Indonesia Wooden Furniture Export Demand Function
}

\author{
Hanna Sri Meiliani Uli Simangunsong, Bintang Charles Hamonangan Simangunsong ${ }^{*}$, Elisa Ganda Togu \\ Manurung \\ Department of Forest Products, Faculty of Forestry and Environment, IPB University. Jl. Ulin, Kampus IPB Darmaga Bogor, \\ 16680, Bogor, Indonesia \\ * Corresponding author. E-mail address: bintangdhh@ipb.app.ac.id
}

\section{ARTICLE HISTORY}

Received: 20 November 2020

Peer review completed:31 January 2021

Received in revised form: 16 February 2021

Accepted: 12 March 2021

\section{KEYWORDS:}

Export demand function

Panel data regression

Wooden furniture

(C) 2021 The Author(s). Published by Department of Forestry, Faculty of

Agriculture, University of Lampung in collaboration with Indonesia Network for Agroforestry Education (INAFE).

This is an open access article under the CC BY-NC license:

https://creativecommons.org/licenses/by$\mathrm{nc} / 4.0 \%$

\begin{abstract}
The export value of Indonesia's wooden furniture was sharply decreased by about $31.9 \%$ over the period in $2007-2018$. On the other hand, global wooden furniture export was increased by $5.8 \%$ during the same period. Understanding the behavior of the demand side of Indonesia's wooden furniture exports that is reflected by its relative price and income elasticities is needed for the policy development of Indonesia's wooden furniture industry in the future. The objective of this study was to estimate the export demand function of Indonesia wooden furniture using a panel data regression model. Three types of panel data models, such as pooled ordinary least squares model, fixed-effects model, and random effects model, were investigated. The results showed that the export demand function of Indonesia wooden furniture could be well estimated using the fixed effects model. Relative price elasticity and income elasticity were -0.45 and 0.8 , respectively. The adjusted $\mathrm{R}^{2}$ value obtained was 0.99 .
\end{abstract}

\section{Introduction}

One of the forest products industries that play an important role in Indonesia's economy is the wooden furniture industry. The Ministry of Industry (2020) reported that exports of the furniture industry in 2019 reached USD 1.95 billion. Furniture is a high added-value product and globally competitive and becomes a strategic commodity (Salim and Munadi 2017). In addition, the furniture industry is a labor-intensive industry that can employ a large number of workers. The Indonesian Furniture and Handicraft Association (AMKRI) explained that Indonesia's furniture industry employed approximately 500 thousand direct workers and 2.5 million indirect workers (AMKRI 2015). In addition, AMKRI (2015) also estimated that each USD 1 billion growth in furniture exports could provide 400-500 thousand jobs.

Furniture trade is one of the important components in the world trade for the category of manufactured products, with the export volume growing quite rapidly every year (Purnomo et al. 2011). The rapid growth in the volume of world exports would increase domestic production capacity, which has an impact on increasing employment and foreign exchange. In addition, the furniture industry is currently attracting great interest from both local and international 
entrepreneurs to continue producing due to the promising value of that product (Kurniawati and Yanti 2018).

The Asia Pacific region was the largest furniture producer globally, with a share accounted for 55\%, followed by America 26\%, Europe 14\%, and the remaining 5\% spread across other regions (CSIL 2016). China, Malaysia, India, Thailand, and Indonesia were the largest producing countries in the Asia Pacific region. The processed UN Comtrade (2020)'s data showed that China in 2018 was the largest furniture exporter globally, a share to the world export value reaching $27.5 \%$. In contrast, Indonesia's share to the world export value was about $2.0 \%$ and ranked eleventh. This condition shows that Indonesia's role as a furniture exporter is still relatively small.

The export value of Indonesian furniture products was dominated by wooden furniture. The export value of Indonesian wooden furniture was USD 1.5 billion in 2007 and decreased to USD 1.1 billion in 2018 , a decrease by $31.9 \%$ or $3.4 \%$ per year (UN Comtrade 2020 ). On the other hand, during the same period 2007-2018, the world wooden furniture exports increased by $5.8 \%$ or $0.5 \%$ per year. To understand the demand-side behavior of furniture exports, important parameters such as price and income elasticities need to be estimated. The price and income are explanatory variables that have the most significant influence in determining export demand behavior. Therefore, this study aims to estimate the export demand function of Indonesian wooden furniture in the world using an econometric model with panel data regression model. This technique has never been used for exports of Indonesian furniture products. Similar studies have been carried out at a country level, including Egypt (Ibrahim 2012) and Israel (Lavee et al. 2016).

\section{Materials and Methods}

\subsection{Data Collection}

The estimation of the demand function for wooden furniture exports used panel data on total quantity and total value of Indonesian wooden furniture exports to 15 destination countries in the period 2007-2018. The studied wooden furniture is a product with the Harmonized System Code (HS) of 9403, which includes 4 commodities such as wooden furniture for office use (HS 940330), kitchen use (HS 940340), bedroom use (HS 940350), and other than for office, kitchen or bedroom use (HS 940360). 15 export destination countries were selected based on the availability and completeness of the latest annual data and together accounted for $85 \%$ of the total export value over the period 2007-2018. Data on quantity (in kg) and export value (in USD) were obtained from the United Nations Commodity and Trade (UN Comtrade 2020). In addition, panel data on Gross Domestic Product (GDP), GDP deflator, and exchange rates (exchange rates) of 15 export destination countries for the period 2007-2018 were also used. Data on GDP (in USD), GDP deflator (in index with various base years), and exchange rates (in local currency units/USD) were obtained from the World Bank (2020).

The nominal price of Indonesian wooden furniture was determined by dividing the total export value by the total export quantity and expressed in USD per tonne. The nominal price of wooden furniture from a competitor country (Malaysia) was also determined in the same way, which was dividing the total export value with the total export quantity from the competitor country (Malaysia) and expressed in USD per tonne. 
Then, all values used were expressed in real terms with the same base year of the 2010 year. Therefore, the GDP deflator for the 15 export destination countries, including Indonesia, needs to be equalized in the base year. The real value (price and GDP) was obtained by: ((nominal value in a given year $\times$ exchange rate in a given year)/GDP deflator in a given year)/exchange rate in 2010). Furthermore, the relative price was obtained by dividing the real price of Indonesian wooden furniture by the real price of wooden furniture from a competitor country (Malaysia). The data were analysed using Microsoft Excel 2016 and Eviews 10. Statistical descriptions for export quantity, relative price of wooden furniture exports, and real GDP of export destination countries are presented in Table 1.

Table 1. The statistical description of the quantity, relative price, and real GDP of the wooden furniture export destination countries in the period 2007-2018

\begin{tabular}{|c|c|c|c|c|c|c|c|c|c|c|c|c|}
\hline \multirow{2}{*}{$\begin{array}{c}\text { Destination } \\
\text { Country }\end{array}$} & \multicolumn{4}{|c|}{ Export quantity (thousand tons) } & \multicolumn{4}{|c|}{ Relative price } & \multicolumn{4}{|c|}{ Real GDP (Billion USD) } \\
\hline & Mean & SD & Min & Max & Mean & SD & Min & Max & Mean & SD & Min & Max \\
\hline Australia & 12.8 & 5.2 & 8.2 & 23.6 & 0.88 & 0.24 & 0.53 & 1.21 & 1,445 & 203 & 1,038 & 1,727 \\
\hline Belgium & 11.0 & 4.1 & 7.3 & 19.5 & 0.89 & 0.11 & 0.78 & 1.13 & 498 & 20 & 469 & 533 \\
\hline China & 4.5 & 1.7 & 2.1 & 8.0 & 0.62 & 0.08 & 0.50 & 0.76 & 8,536 & 2,415 & 4,586 & 12,308 \\
\hline France & 27.4 & 10.4 & 15.0 & 54.3 & 0.64 & 0.16 & 0.46 & 1.00 & 2,736 & 99 & 2,584 & 2,926 \\
\hline Germany & 9.8 & 2.4 & 6.5 & 13.6 & 0.75 & 0.13 & 0.57 & 0.93 & 3,607 & 200 & 3,273 & 3,941 \\
\hline Italy & 5.0 & 2.9 & 2.6 & 12.0 & 0.75 & 0.09 & 0.55 & 0.88 & 2,113 & 60 & 2,043 & 2,234 \\
\hline Japan & 69.3 & 11.5 & 47.3 & 83.7 & 0.52 & 0.07 & 0.43 & 0.69 & 5,869 & 203 & 5,471 & 6,190 \\
\hline Netherlands & 18.6 & 6.2 & 11.8 & 29.2 & 0.72 & 0.11 & 0.59 & 0.97 & 872 & 35 & 833 & 949 \\
\hline New Zealand & 1.5 & 0.5 & 0.9 & 2.3 & 0.84 & 0.13 & 0.63 & 1.11 & 160 & 15 & 144 & 186 \\
\hline Rep. of Korea & 9.3 & 1.2 & 7.9 & 12.1 & 0.74 & 0.11 & 0.56 & 0.94 & 1,180 & 131 & 992 & 1,382 \\
\hline Singapore & 4.0 & 2.3 & 2.2 & 11.0 & 0.72 & 0.10 & 0.52 & 0.84 & 277 & 47 & 205 & 342 \\
\hline Spain & 6.8 & 5.3 & 2.5 & 19.5 & 0.69 & 0.08 & 0.61 & 0.86 & 1,439 & 58 & 1,353 & 1,549 \\
\hline Thailand & 0.5 & 0.2 & 0.3 & 1.0 & 0.87 & 0.24 & 0.53 & 1.35 & 288 & 31 & 242 & 336 \\
\hline United Kingdom & 28.2 & 9.0 & 19.4 & 53.5 & 0.56 & 0.22 & 0.36 & 1.07 & 2,611 & 149 & 2,412 & 2,858 \\
\hline USA & 114.9 & 8.0 & 103.1 & 132.5 & 1.19 & 0.16 & 0.92 & 1.39 & 15,949 & 1,062 & 14,617 & 17,844 \\
\hline
\end{tabular}

Source: UN Comtrade 2020.

\subsection{Export Demand Function}

In general, the export demand function of a particular commodity is derived from the theory of consumer demand (Nicholson and Snyder 2012) as shown by Equation 1:

$$
X_{i t}=f\left(P_{i t}, P_{j t}, \ldots P_{k t}, I_{t}, Z_{t}, U_{t}\right)
$$

where:

$X_{i t} \quad=$ export commodity $i$ at time $t$

$P_{i t} \quad=$ export price of commodity $i$ at time $t$

$P_{j t}, \ldots, P_{k t}=$ other commodity prices $(j, \ldots, k)$ at time $t$

$I_{t} \quad=$ income of other countries (importers) at time $t$

$Z_{t} \quad=$ other explanatory variables at time $t$

$U_{t} \quad=$ disturbance or error at time $t$

The requirement for $U_{t}$ is that it be independent of the other explanatory variables, be free from autocorrelation, and have consistent variance. 
Understanding the export demand shifters helps reduce most of the risk and uncertainty in decision-making related to international trade. Several export demand shifters related to international trade in forest products can be known from previous studies (Ashraf et al. 2018; Baudin 1987; Blatner 1989; Buongiorno 1979, 2015, 2019; Cengel and McKillop 1990; Chang 1987; Chou and Buongiorno 1983; Garcia 1987; Nanang 2010; Vincent et al. 1991; Yukutoke 1984). Export demand shifters are explanatory variables, and the ones considered are usually those explanatory variables that have most significant influence in determining the behavior of commodity export demand, so that Equation 1 is conventionally postulated to be a simpler equation as presented in Equation 2 (Djaja 1992):

$$
X_{i t}=f\left(P_{i t}, P_{k t}, I_{t}, U_{t}\right)
$$

when the effect of inflation (money illusion) is assumed to be non-existent, then all variables in Equation 2 are expressed in the real values and without measurement errors.

In the import demand function modeling, importing countries are usually assumed to only face competition from domestic producers. In the export demand function modeling, exporting countries face competition, not only from domestic producers in competing regions, but also from other exporting countries to that region. Goldstein and Khan (1985) and Ibrahim (2012) observed that the conventional practice in specifying the export demand equation is to assume a dominant relative price competition among exporters. Therefore, the relative price used in the export demand equation is only the ratio of the export price $(P t)$ of a country to the export price of its competitor $(P k t)$ for the same commodity. The export demand function can be expressed by Equation 3:

where:

$$
X_{i t}=f\left(R P_{i t}, I_{t}, U_{t}\right)
$$

$R P_{i t} \quad=P_{i t} / P_{i k t}$; relative price

$P_{i k t} \quad=$ export price of the same commodity $(i)$ from a competitor country $(k)$

This study used a double log-linear transformed data in estimating the wooden furniture export demand function parameters. The choice of this data transformation form produces parameters, which describes: the main characteristic of the demand function; is easy to interpret, such as elasticity; and takes advantages of using the panel data regression model in estimation as described later. The function of export demand for wooden furniture in double log-linear form is shown by Equation 4 (Gujarati and Porter 2009):

where:

$$
\log X_{t}=a_{0}+a_{1} \log R P_{t}+a_{2} \log I_{t}+U_{t}
$$

$R P_{t}=P_{t} / P_{k t}$

$X_{t}=$ export wooden furniture at time $t$

$P_{t}=$ export price of wooden furniture at time $t$

$P_{k t}=$ export price of wooden furniture from competitor country $(k)$ at time $\mathrm{t}$

$I_{t}=$ the income of the importer country at time $t$

$U_{t}=$ disturbance at time $t$

Equation 4 implies that $a_{1}$ and $a_{2}$ are, respectively, relative price and income elasticities. The relative price elasticity is expected to be negative, while the income elasticity is expected to be positive. 


\subsection{Panel Data Model Regression}

Equation 4 was estimated using panel data model regression. Panel data model regression analysis combines cross section data (export data to the various destination countries at a certain time) and time series data (export data to a destination country over a certain period). Gujarati and Porter (2009) stated some of the advantages obtained when using panel data regression models, including: (a) being able to identify and measure effects that simply cannot be overcome in pure cross section data or pure time series data, (b) being able to control individual heterogeneity, (c) being able to provide more informative data, reduce collinearity between variables and increase degrees of freedom so that data becomes more efficient, and (d) reducing heteroscedasticity when data is transformed into logarithmic form because it compresses the scale of the size of the variables.

Three kinds of panel data models were investigated to obtain the best export demand function, such as the pooled ordinary least squares model, the fixed effects model, and the random effects model.

\subsubsection{Pooled ordinary least squares model}

This approach assumes the intercept and slope of the regression equation to be the same accros country and over time, as shown in Equation 5. All cross section and time series data will be used to estimate the parameters of Equation 5 using the Ordinary Least Squares (OLS) method. where:

$$
Y_{i t}=\alpha+\beta^{\prime} x_{i t}+u_{i t}
$$

$Y_{i t} \quad=$ the export value of wooden furniture products to the country $\mathrm{i}$ at time $\mathrm{t}$

$x_{i t} \quad=$ exogenous variables $\left(R P_{i t}\right.$ and $\left.I_{t}\right)$

$\alpha=$ intercept

$\beta \quad=$ slope $\left(\beta_{1}, \beta_{2}\right)$

$i \quad=$ export destination country

$t \quad=$ at time $t(t=2007,2008, \ldots, 2018)$

$u \quad=$ disturbance

\subsubsection{Fixed-effects model}

Assuming the intercept and slope of the regression equation to be the same across country and over time are considered less suitable for using panel data. To overcome this, the fixed effect model as shown in Equation 6 was investigated. This model assumes a different and constant intercept but the elasticity parameters (slopes) are the same and constant for all countries. Dummy variables are added to the model to allow differences in intercept among countries and then estimated using the OLS method, which is- known as the Least Squares Dummy Variable (LSDV).

$$
Y_{i t}=\alpha_{i}+\beta^{\prime} x_{i t}+u_{i t}
$$

where $\alpha_{i}$ is the specific effect of country $i$ and constant over time.

\subsubsection{Random-effects model}

The dummy variable that is added into the regression model will reduce degrees of freedom and then reduce the efficiency of the estimated parameter. A random effects modeling approach 
can be used to overcome this problem, instead. This random-effects model is also called the error component model because the differences among countries are allowed through the random term (disturbance) rather than through the constant in the model, as shown in Equation 7:

$$
Y_{i t}=\alpha+\beta^{\prime} x_{i t}+v_{i}+u_{i t}
$$

where $v_{i}$ is random-effect of country $i$.

\subsection{Classic Assumption Test}

Two assumptions in regression analysis that a model should be satisfied are free from heteroscedasticity and autocorrelation. Heteroscedasticity means that the variability of the error is not constant or varies due to the very different observed values of the variable or several variables or due to the outlier data. Although the estimated parameter value is not biased and consistent, but its variance is not efficient. The heteroscedasticity in panel data was detected using the General Least Squares (GLS) method that if the sum squares residual on the weighted statistic are smaller than that sum squares residual on the unweighted statistic. Then, heteroscedasticity was corrected by re-estimating the equation using the GLS method with white heteroscedasticity.

Autocorrelation occurs when there is a linear relationship between one error term and another error term. Although this autocorrelation does not cause the parameters to be biased, the parameter estimation is not efficient. Autocorrelation in a model can be detected by looking at the Durbin Watson (DW) statistical value. The first-order autocorrelation, both positive and negative, is assumed to be absent when the DW value is around 2 (Gujarati and Porter 2009).

\subsection{Model Selection}

The selection of the most efficient and best model among the three models are based on three statistical tests, such as the Chow test, Hausman test, and The Breusch-Pagan LM Test (Gujarati and Porter 2009). Statistical criteria including the parameter sign being in accordance with the theorysignificance of parameters, and a good adjusted $\mathrm{R}^{2}$ (power of explanation) value were also used in the selection of the model.

\subsubsection{Chow Test}

The Chow test that is commonly called the F statistics test, is a statistical test that aims to choose between the fixed effects model and the pooled ordinary least squares model. The hypothesis being tested is following:

$\mathrm{H}_{0}$ : Pooled ordinary least squares model $\left(\alpha_{1}=\alpha_{2}=\ldots=\alpha_{\mathrm{n}}\right.$ given $\left.\beta_{\mathrm{i}}=\beta_{2}=\ldots=\beta_{\mathrm{n}}\right)$

$\mathrm{H}_{1}$ : Fixed effects model $\left(\alpha_{1} \neq \alpha_{2} \neq \ldots \neq \alpha_{\mathrm{n}}\right.$ given $\left.\beta_{1} \neq \beta_{2} \neq \ldots=\beta_{\mathrm{n}}\right)$

If the test results are significant with the criteria (probability of chow $<\alpha$ ), then reject $\mathrm{H}_{0}$, so the model used is the fixed effects model.

\subsubsection{Hausman Test}

The Hausman Test is a statistical test to choose between the fixed effects model and the random-effects model. Hypothesis testing for this test is following:

$\mathrm{H}_{0}:$ Random-effects model $\left(\mathrm{E}\left(\alpha_{\mathrm{i}} \mid \mathrm{x}_{\mathrm{i}}\right)=0\right)$

$\mathrm{H}_{1}$ : Fixed-effects model $\left(\mathrm{E}\left(\alpha_{\mathrm{i}} \mid \mathrm{x}_{\mathrm{i}}\right) \neq 0\right)$ 
The Hausman statistical value will be compared with the chi-square value as the basis of rejecting $\mathrm{H}_{0}$. If the statistical value of the test results is higher than the chi-square table, there is sufficient evidence to reject $\mathrm{H}_{0}$, so the used approach is the fixed effects model.

\subsubsection{The Breusch-Pagan Lagrange Multiplier Test}

The Breusch-Pagan Lagrange Multiplier (LM) Test is used as a basis for statistical considerations in choosing between the random-effects model and the pooled ordinary least squares model. Hypothesis testing for this test is following:

$\mathrm{H}_{0}$ : Pooled ordinary least squares model $\left(\sigma_{v}^{2}=0\right)$

$\mathrm{H}_{1}$ : Random-effects model $\left(\sigma_{v}^{2} \neq 0\right)$

The rejection basis of $\mathrm{H}_{0}$ is by comparing the $\mathrm{LM}$ statistical value with the chi-square value. If the calculated LM value is higher than the chi-square table, $\mathrm{H}_{0}$ is rejected, so the random-effects model is used.

\section{Results and Discussion}

The estimation results in the form of parameters of relative price and income elasticities along with related statistical tests of the export demand function for Indonesian wooden furniture of three kinds of panel data models: the pooled ordinary least squares model (Equation 5), the fixed effects model (Equation 6), and the random-effects model (Equation 7) are presented in Table 2, Table 3, and Table 4.

Table 2. The results of the initial estimation of the panel data analysis

\begin{tabular}{|c|c|c|c|c|c|c|c|c|c|}
\hline \multirow{2}{*}{ Item } & \multicolumn{3}{|c|}{ Pooled Model } & \multicolumn{3}{|c|}{ Fixed-Effect Model } & \multicolumn{3}{|c|}{ Random-Effect Model } \\
\hline & Coef & Std. Error & Prob. & Coef & Std. Error & Prob. & Coef & Std. Error & Prob. \\
\hline \multicolumn{10}{|l|}{ Variable } \\
\hline $\mathrm{C}$ & -3.37 & 0.44 & 0.00 & 2.71 & 1.89 & 0.15 & -0.90 & 1.24 & 0.47 \\
\hline LRPRICE & -0.12 & 0.28 & 0.68 & -0.11 & 0.15 & 0.47 & -0.21 & 0.15 & 0.15 \\
\hline LRGDP & 0.76 & 0.06 & 0.00 & -0.07 & 0.26 & 0.78 & 0.42 & 0.16 & 0.01 \\
\hline \multicolumn{10}{|l|}{ Statistics } \\
\hline R-squared & 0.48 & & & 0.94 & & & 0.04 & & \\
\hline Adjusted R-squared & 0.47 & & & 0.94 & & & 0.03 & & \\
\hline S.E. of regression & 1.01 & & & 0.35 & & & 0.36 & & \\
\hline F-statistic & 81.64 & & 0.00 & 165.97 & & 0.00 & 3.56 & & 0.03 \\
\hline Durbin-Watson stat & 0.07 & & & 0.63 & & & 0.56 & & \\
\hline
\end{tabular}

Table 3. Statistical test for the export demand function

\begin{tabular}{lccc}
\hline Test & Type & Value & Prob. \\
\hline Heteroscedasticity & & & \\
in cross-section & LR test & 194.5 & 0.00 \\
in period & LR test & 5.32 & 0.99 \\
Chow's test & F stat & 5.78 & 0.00 \\
Breusch-Pagan Test & LM test & 749.32 & 0.00 \\
Hausman test & Chi-square & 6.23 & 0.04 \\
\hline
\end{tabular}


The pooled ordinary least squares model that assumes the same and constant intercept and elasticity parameters (slopes) across country and over time were estimated using the Least Squares Panel technique, and the results showed a significant positive serial correlation as indicated by the Durbin-Watson (DW) value 0.07 (Table 2). The heteroscedasticity test further showed error variance of the pooled ordinary least squares model was not constant. Heterogeneity stemmed from cross-sections, various country as indicated by the value of the Likelihood Ratio (LR) $=194.5$ with $p$-value $=0.00$; and not from the time series, various year, as indicated by the value of LR $=$ 5.32 with p-value $=0.99$ (Table 3 ). The presence of positive serial correlation and heteroscedasticity requires correction hence this pooled ordinary least squares model was reestimated using the Feasible Generalized Least Squares (FGLS) technique with robust error and the results were shown in Table 4. Relative price elasticity and income elasticity had signs as expected, that is -0.40 and 1.02 , respectively, and both were significantly different from 0 at the marginal significance level (p-value) 0.00 and 0.00 , respectively. The obtained adjusted coefficient of determination $\left(\mathrm{R}^{2}\right)$ was 0.98 such an excellent value for a simple model.

Table 4. The best estimation results of panel data analysis

\begin{tabular}{|c|c|c|c|c|c|c|c|c|c|}
\hline \multirow{2}{*}{ Item } & \multicolumn{3}{|c|}{ Pooled Model } & \multicolumn{3}{|c|}{ Fixed-Effect Model } & \multicolumn{3}{|c|}{ Random-Effect Model } \\
\hline & Coef & Std. Error & Prob. & Coef & Std. Error & Prob. & Coef & Std. Error & Prob. \\
\hline \multicolumn{10}{|l|}{ Variable } \\
\hline $\mathrm{C}$ & -6.61 & 2.58 & 0.01 & -4.03 & 1.89 & 0.04 & -0.90 & 1.86 & 0.63 \\
\hline LRPRICE & -0.40 & 0.13 & 0.00 & -0.45 & 0.09 & 0.00 & -0.21 & 0.18 & 0.25 \\
\hline LRGDP & 1.02 & 0.28 & 0.00 & 0.81 & 0.26 & 0.00 & 0.42 & 0.24 & 0.09 \\
\hline \multicolumn{10}{|l|}{ Statistics } \\
\hline R-squared & 0.98 & & & 0.99 & & & 0.04 & & \\
\hline Adjusted R-squared & 0.98 & & & 0.99 & & & 0.03 & & \\
\hline S.E. of regression & 0.24 & & & 0.21 & & & 0.36 & & \\
\hline F-statistic & $2,936.33$ & & 0.00 & $1,002.66$ & & 0.00 & 3.56 & & 0.03 \\
\hline Durbin-Watson stat & 2.12 & & & 2.24 & & & 0.56 & & \\
\hline
\end{tabular}

The fixed effects model that assumes different and constant intercepts, but the same and constant elasticity parameters (slopes) for all countries were estimated using the Least Squares Panel technique and the results showed all parameters were not significantly different from 0 at a significance level of 0.05 with a DW value of 0.63 ,indicating a significant positive serial correlation (Table 2). The obtained DW value for this fixed effects model was about 9 times of that obtained for the pooled ordinary least squares model, but it was still much smaller than 2.00 (the reference value that is considered free of serial correlation). The presence of positive serial correlation requires correction so that fixed effects model was re-estimated using the Least Squares with AR (1) correction technique, but positive serial correlation was still persisted. To obtain the best results, the fixed effects model was then estimated using the FGLS technique with robust error, and the results were presented in Table 4. The value of the intercept (-4.03) was significantly different from 0 at the significance level of 0.05 , which justifies the assumption of different intercept across country. Relative price elasticity and income elasticity had signs as expected, which were -0.45 and 0.81 , respectively; and both were statistically very different from 0 . The adjusted coefficient of determination $\left(\mathrm{R}^{2}\right)$ was 0.99 , and this value was higher than that value obtained from the pooled ordinary least squares model indicating the importance of country effect. Chow's test confirmed that the country intercepts were different for each country (heterogeneous) 
as indicated by the statistical value of $F=5.78$ with $p$-value $=0.00$ (Table 3 ). This implied that the fixed effects model (Equation 6) was more appropriate to estimate export demand function than the pooled ordinary least squares model (Equation 5).

The random-effects model that assumes the same and constant intercept and elasticity parameters (slopes) across country, but different random error for each country; was estimated using the Least Squares Panel technique, and the results showed a significant positive serial correlation as indicating by the value of DW $=0.56$ (Table 2). This DW value was slightly smaller than that DW value for the fixed effects model. The presence of positive serial correlation requires correction so that random-effects model was re-estimated using the FGLS technique with robust error, and the results were presented in Table 4. Relative price elasticity and income elasticity had signs as expected, which were -0.21 and 0.42 , respectively. However, both were not significantly different from 0 at the marginal significance level (p-value) of 0.25 and of 0.09 , respectively. The Breusch-Pagan test (Lagrange Multiplier test) confirmed that country error was different for each country and does not correlate with relative price and income as indicated by the statistical value $\mathrm{LM}=749.32$ with $\mathrm{p}$-value $=0.00$ (Table 3 ). This implied that random-effects model was relatively more appropriate than the pooled ordinary least squares model to estimate export demand function. However, the Hausman test with a chi-square value $=6.23$ and $p$-value $=0.04$ (Table 3) indicates a specification error of the random-effects model compared to the fixed-effects model. The obtained adjusted coefficient of determination $\left(\mathrm{R}^{2}\right)$ with the random-effects model (0.03) was also much lower than that was obtained with the fixed effects model (0.99).

Although the relative price and income effects have been considered as shown by various statistical tests (Chow test and Breusch-Pagan test), the pooled ordinary least squares model was not appropriate to be used to estimate the export demand function of Indonesian wooden furniture due to the large difference among countries, On the other hand, when specifies errors of the random-effects model was detected by the Hausman test and the adjusted $\mathrm{R}^{2}(0.03)$ value was very low, the random-effects model cannot be used to explain variations in export demand. The fixedeffects model was thenmore appropriate to use than those two models above. In addition the relative price elasticity $(-0.45)$ and income elasticity $(0.81)$ had signs as expected (in accordance with theory), and both were significantly very different from 0 . The obtained adjusted $\mathrm{R}^{2}$ value was also very high (0.99) so it can be relied on to explain the exports demand variation of Indonesian wooden furniture very well.

Similar results were obtained by Ibrahim (2012) when using the fixed effects model to estimate the demand function for Egyptian export goods. The obtained income and relative price elasticities were in accordance with the theory and statistically significant. However, Buongiorno (2019) showed that the quadratic programming method of country-specific elasticities might be used to improve the estimation of the export demand for Indonesian wood furniture from each destination country.

\section{Conclusions}

The export demand function of Indonesian wood furniture products can be estimated properly using the fixed effects model. The obtained values of relative price and income elasticities were, respectively, -0.45 and 0.81 with a high adjusted $\mathrm{R}^{2}$ value (0.99). When the ratio of the real price of Indonesian wooden furniture to the real price of competitor country's wooden furniture increases by $1 \%$, the export demand for Indonesian wood furniture products would decrease by 
$0.45 \%$, ceteris paribus. When the real GDP (income) of export destination countries increases by $1 \%$, the export demand for Indonesian wood furniture products would increase by $0.81 \%$, ceteris paribus. Ninety-nine percent (99\%) export demand variation of Indonesian wooden furniture products can be explained using relative price and income as explanatory variables. An income elasticity value smaller than 1 indicates that the exported Indonesian wooden furniture is normal goods, not luxurious goods. The production of furniture made from fancy wood such as teak that produces luxury goods should be increased to boost foreign exchange earnings from exports of wooden furniture products.

\section{References}

AMKRI. 2015. Roadmap Industri Mebel dan Kerajinan Indonesia. Asosiasi Mebel dan Kerajinan Indonesia (AMKRI), Jakarta, Indonesia.

Ashraf, H., Khan, I. H., Javaid, A., and Awais, M. 2018. Price and Income Elasticities of Crude Oil Demand: Cross Country Analysis. European Online Journal of Natural and Social Science 7(1): 122-136.

Baudin, A. 1987. The Demand of Sawnwood in Norway. Forest Sector and Trade Models: Theory and Applications. Center for International Trade in Forest Products, University of Washington, Seattle.

Blatner, K. A. 1981. An Approach to The Estimation of Import Price Elasticity by Supplier. Forest Science 35: 30-41. DOI: 10.1093/forestscience/35.1.30

Buongiorno, J. 1979. A Monthly Model of The United States Demands for Softwood Lumber Imports. Forest Science 25: 751-755. DOI: 10.1093/forestscience/25.4.641

Buongiorno, J. 2015. Income and Time Dependence of Forest Product Demand Elasticities and Implications for Forecasting. Silva Fennica 49(5): 1-17. DOI: 10.14214/sf.1395

Buongiorno, J. 2019. Country-Specific Demand Elasticities for Forest Products: Estimation method and Consequences for Long Term Projections. Forest Policy and Economics 106: 1-7. DOI: 10.1016/j.forpol.2019.101967

Cengel, D. W., and McKillop, W. 1990. US Trade in Transition - an Econometric View of South Sea Wood Flows. Forest Science 36: 425-437. DOI: 10.1093/forestscience/36.2.425

Chang, S. J. 1987. An Econometric Analysis of Supply and Demand for Forest Products in Taiwan. Forest Products Trade: Market Trends and Technical Development. University of Washington, Seattle.

Chou, J. J., and Buongiorno, J. 1983. United States Demand for Hardwood Plywood Imports by Country of Origin. Forest Science 29: 225-237. DOI: 10.1093/forestscience/29.2.225

CSIL. 2016. World Furniture Market. <https://www.iffs.com.sg/industry-news/currentstatusasias-furniture-production-markets/> (April 15, 2018).

Djaja, K. 1992. Export performance and export demand of Indonesian forest products. The RTD. Iowa State University, Iowa. DOI: 10.31274/rtd-180813-11505

Garcia, J. M. P. 1987. Implication of Using Exchange Rates for Estimate of Income and Price Elasticity in Paper Demand Studies. Forest Sector and Trade Models: Theory and Applications. University of Washington, Seattle.

Goldstein, M., and Khan, S. 1985. Income and price effects in foreign trade. In Jones $R$, Kenen P. 1985. Handbook of International Economics. McGraw Hill, Boston. DOI: 10.1142/9789814749589 0001 
Gujarati, D. N., and Porter, D. C. 2009. Basic Econometric. $5^{\text {th }}$ Edition. McGraw Hill, New York. Ibrahim, M. A. 2012. Merchandise Export Demand Function for Egypt: A Panel Data Analysis. Applied Econometrics and International Development 12(1): 107-116.

Kurniawati, D., and Yanti, A. R. 2018. Tantangan Eksportir Furnitur di Yogyakarta, Studi Kasus CV. Dbest Furniture. Jurnal Balance 15(1): 71-79. DOI: 10.30651/blc.v15i01.1261

Lavee, D., Agbaria, A., and Shvartzman, T. 2016. Estimation of the Export Demand Function Using Panel Data: The Case of Israel. International Journal Trade and Global Market 9(4): 305-324. DOI: 10.1504/ijtgm.2016.081149

Nanang, D. M. 2010. Analysis of Export Demand for Ghana's Timber Products: A Multivariate Co-Integration Approach. Journal of Forest Economics 16: 47-61. DOI: 10.1016/j.jfe.2009.06.001

Nicholson, W., and Snyder, C. 2012. Microeconomic Theory: Basic Principles and Extensions, Eleventh Edition. South-Western, Cengage Learning. Mason, Ohio, USA.

Porter, M. E. 1990. The Competitive Advantage of Nations. Free Press, New York.

Purnomo, H., Irawati, R. H., and Wulandari, R. 2011. Kesiapan Produsen Mebel di Jepara dalam Menghadapi Sertifikasi Ekolabel. Jurnal Manajemen Hutan Tropika 17(3): 127-134. DOI: $10.7226 / \mathrm{jtfm} .17 .3 .127$

Salim, Z., and Munadi, E. 2017. Info Komoditi Furnitur. Badan Pengkajian dan Pengembangan Perdagangan, Kementerian Perdagangan Republik Indonesia, Jakarta.

The Ministry of Industry of Indonesia. 2020. Kebijakan Pengembangan Industri untuk Penguatan Daya Saing Produk Hasil Hutan. Webinar Aplikasi Undang-Undang Cipta Kerja dalam Rangka Peningkatan Nilai Tambah Industri Hilir Kayu Nasional. Jakarta: 17 September 2020.

UN Comtrade. 2020. International Trade Statistics Database. https://comtrade.un.org/data/.

Vincent, J. R. 1991. Substitution Between Tropical and Temperate Sawlogs. Forest Science 36: 657-664. DOI: 10.1093/forestscience/37.5.1484

Yukutoke. 1984. Econometric Analysis of South Seas and USSR Log Market in Japan. Agribusiness Resource Quarterly 17:269-279. 